\title{
Astronomers buoyed by rejection of merger
}

\section{Tony Reichhardt, Washington}

Astronomers have welcomed the rejection by a top level panel of a proposal to subsume into NASA the ground-based astronomy programme run by the National Science Foundation (NSF).

The White House had suggested earlier this year that NASA should take control of the programme as a way to reorganize federal funding for astronomy, but the plan was unpopular among scientists from the start. Researchers feared, among other things, that the mission-oriented space agency would not be as guided by scientific priorities as the NSF (see Nature 410, 853; 2001).

After carrying out a fast-track study ordered by the White House, the panel from the US National Academy of Sciences chaired by Norman Augustine, former chief executive of Lockheed Martin - flatly rejected the idea. Its report instead recommends establishing a high-level joint advisory committee to supervise both agencies' astronomy programmes.

"The NSF is the right institution to sponsor ground-based astronomy and astrophysics," the study concludes, adding that a simple transfer to NASA "would have a net disruptive effect on scientific work". Astronomers are "pretty happy" with this unambiguous conclusion, says Kevin Marvel, a policy specialist with the American
Astronomical Society in Washington. The society, whose members sent hundreds of emails to the panel during the study period, is preparing its formal response to the report.

Instead of creating a single 'super-agency' for astronomy, Augustine's panel recommends that the White House science office and its Office of Management and Budget create a new interagency planning board for astronomy and astrophysics, with membership drawn from the energy and defence departments, the Smithsonian Institution and other secondary players in astronomy, as well as from NASA and the NSF. The coordinated interagency programme could be modelled on the US Global Change Research Program, it suggests.

The NSF's astronomy division would benefit from having a permanent advisory committee like NASA's, the panel says, which would help allay concerns that the NSF is struggling to manage ground-based astronomy projects, including the \$600-million Atacama Large Millimeter Array (ALMA) radio telescope planned in Chile. "Several staff members in the Executive Branch and in Congress conveyed to the committee their perception that NSF does not manage large projects well," says the report.

Yet this may be just a perception. Augustine's group "did not find evidence" that the NSF had significantly more problems during the construction phase of large projects than did NASA, the Department of Energy, or other similar agencies. But the NSF has communicated its strategies for these projects poorly to the White House and Congress, says the report - a complaint echoed last week in a House of Representatives science committee hearing on the NSF's management of large research facilities.

Even with more regular advice from the scientific community, and after strengthening its communication with NASA, the NSF will face an uphill battle in fulfilling astronomers' wishes for large new telescopes, as sources of funding have not been identified. "By a substantial margin, the NSF does not have the resources to keep US ground-based optical and infrared astronomy at the world level," the study panel says.

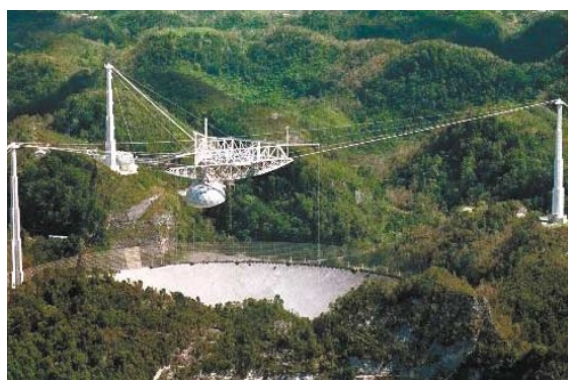

The NSF will still run Puerto Rico's Arecibo dish.

\section{$\mathrm{NIH}$ ponders repository for embryonic stem cells}

\section{Laura Bonetta, Washington}

The US National Institutes of Health (NIH)

is considering plans for a repository to house human embryonic stem cells for distribution to US researchers.

The proposed stem-cell bank would hold many of the 64 embryonic stem-cell lines approved for funding under the Bush administration's recent ruling (see Nature 412, 665; 2001).

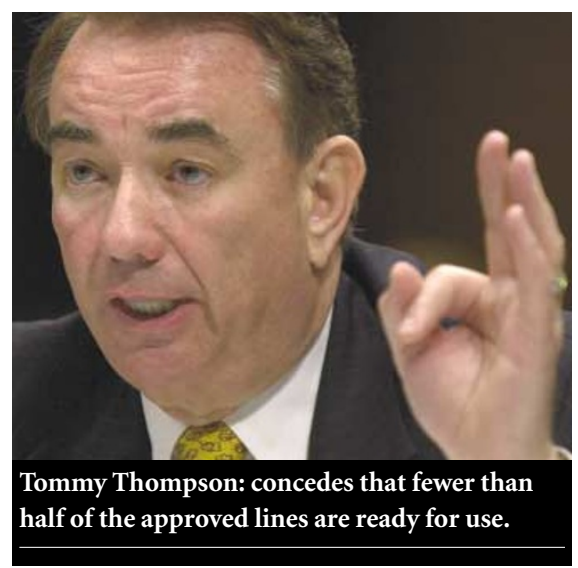

Health secretary Tommy Thompson unveiled the plan at the 5 September hearing of the Senate's Health, Education, Labor and Pensions Committee. Thompson also conceded at the hearing that only 24 or 25 of the 64 approved cell lines are fully developed and "ready to be sent out to researchers".

The repository idea is an extension of the NIH's plan to compile a registry of embryonic stem cells, which will initially include the name of each cell line and contact information for the provider. Supporters of the concept say that a repository might ease researchers' concerns about the quality and accessibility of the cell lines that are eligible for funding.

Although the concept is supported by many scientists and scientific organizations, it is unclear whether providers of embryonic stem cells will agree to it. "Some of the entities that have derived stem cells have expressed interest in a repository, others have not yet addressed this idea, and still others have said they are not interested," says Lana Skirboll, associate director for science policy at the NIH.
Douglas Melton, a stem-cell researcher at Harvard University and an advocate of the repository, told the Senate hearing: "The federal government and the NIH are in an immeasurably stronger position than are individual investigators to obtain the human embryonic stem-cell lines from suppliers, verify their quality, and arrange for their distribution.”

The idea of a human embryonic stem-cell bank is not new. In March 2000, a working group for the Royal Society recommended creating a repository in the United Kingdom, where regulations on stem-cell research are less restrictive than in the United States. In a more recent report, the society said that cell lines would be available to the scientific community on a non-commercial basis, and "funding and ethical permission on stem-cell research could be conditional on any lines being put in the bank".

The Senate committee's hearing was the first of three scheduled for this month, as senators probe the justification for the Bush administration's policy on the funding of stem-cell research. 